JAN KRACIK (PAT KRAKÓW)

\title{
MARSZALEK FUNDUJE KAMEDUŁÓW
}

Styl życia fundatora i tych, których był benefaktorem, był o wiele częściej kontrastowy niż podobny. Kontrast ów wpisywany był wręcz w teologię fundacji, a to przez nawiązanie do świętych i nieświętych obcowania: pokuta i modlitwa o grzechów odpuszczenie żywym i umarłym dobrodziejom współtworzyły wszak rację bytu klasztornego żywota. W ten szablon Mikołaj Wolski wpisał się także,

Urodzony w 1553 r. w Podhajcach chłopięce lata spędził w Krakowie, dokąd go - jak pisał - wysłał ,pan ociec mój, dawszy mi naprzód z dzieciństwa pierwsze wychowanie” oraz „poczattki obiecadła i gramatiki”. Ojciec, Stanisław Wolski, starosta krzepicki udając się w poselstwie do cesarza Maksymiliana II zabrał chłopca do Wiednia. Tam pod okiem pedagoga Mikołaj chłonał humanistyczne scjencje. W towarzystwie arcyksiążąt habsburskich odbył podróż do Brukseli. Liczył 15 lat, gdy ojciec zmarł. Trzeba było wracać, by objąc starostwo krzepickie. Ale edukacji młody Wolski nie zaniedbał, pobierając nauki u znanego mistrza Stanisława Sokołowskiego, ćwicząc się w języku niemieckim, włoskim i francuskim.

Licząc 17 lat wyjechał znów. Zwiedzał Niemcy, Francję, Anglię, Niderlandy, Italię. Interesowało go wszystko: nauki ścisłe, sztuki plastyczne, muzyka. Zetknięcie $\mathrm{z}$ kulturą renesansu ukształtowało upodobania młodego człeka czyniąc go $\mathrm{z}$ czasem mecenasem.

Powrócił, by wziąć udział w I wolnej elekcji. Niebawem znalazł się na dworze króla Henryka otrzymując zgoła tytularny urząd miecznika koronnego. Po ucieczce króla do Francji Wolski włączył się w przedwyborczą kampanię na rzecz Maksymiliana, a przedstawiciel cesarza kierował montowaniem prohabsburskiego stronnictwa właśnie z Krzepic. Po wyborze Stefana Batorego miecznik królewski nie poczekał nawet na koronację i udał się do Pragi, gdzie rezydujący cesarz Rudolf II, znajomy $z$ wiedeńskich lat, uczynił Mikołaja swym podczaszym. Sprawując ten urząd na Hradczanach Wolski bywał w Polsce jako cesarski poseł lub w sprawach osobistych, majatkowych i na sejmikach.

Dnia 12 VI 1583 r. był proszonym gościem na wspaniałym krakowskim weselu Jana Zamojskiego z królewską bratanicą Gryzeldą Batorówną. Po turnieju i defiladzie na Rynku odprawiono na włoski wzór trionfo, w której to paradzie przebierańców Mikołaj Zebrzydowski prowadził wóz z Saturnem jako alegoria 
czasu. Stanisław Żółkiewski w zielonej sukni udawał boginię Dianę, zaś Mikołaj Wolski wystapił „po murzyńsku”. Należał wszak do satyrycznego towarzystwa Rzeczpospolitej Babińskiej przy dworze Pszonków w podlubelskim Babinie.

Cesarska Praga, gdzie Mikołaj spędził 10 lat, różniła się wtedy znacznie od Krakowa. Na Hradczanach odbywano poetyckie turnieje, grała muzyka, kwitło towarzyskie życie. Zajmowano się też modną wówczas alchemia, którą Wolski tak się przejął, że powróciwszy do kraju nie tylko sam ją uprawiał, ale wciagnął do tego zajęcia i króla Zygmunta III, doprowadzając przez to wraz z nim do pożaru Wawelu .

Dla konserwatywnej części szlachty Wolski był uosobieniem cudzoziemszczyzny. Choć podczas elekcji opowiedział się znów za Habsburgiem, Zygmunt Waza powierzył krzepickiemu staroście wysoki urząd marszałka koronnego. Król doceniał bowiem jego wykształcenie, rozmiłowanie w sztuce, łatwość nawiązywania kontaktów, znajomość dyplomacji, biegłe władanie paroma językami. Wolski został bliskim doradcą króla. Odbywał poselstwa do papieża i monarchów, angażował na dwór artystów (np. Santi Gucci, Giovanni Trevani, Tomasz Dolabella), a zwłaszcza muzyków do wawelskiej kapeli, doglądał zakładania włoskich ogrodów i królewskiego zwierzyńca. Wynagradzany kolejnymi starostwami, zgromadził ich 5, nie licząc 7 kluczy własnych dóbr i wielu domów w Krakowie i Warszawie.

Jeśli nie przy dworze a u siebie, to najczęściej przebywał w Krzepicach, 35 $\mathrm{km}$ na północny zachód od Częstochowy. Wykupil okoliczne kuźnice i zmodernizowal produkcję. Przebudowawszy miejscowe zamczysko na pałac, Wolski wyposażył go w stiuki i renesansowe meble oraz ozdobił galerią cennych płócien, jakiej nie było w żadnej prowincjonalnej rezydencji. Była tam i zasobna biblioteka pięknie oprawionych ksiag, było i alchemiczne laboratorium. Marszałek nie tylko gromadził. Kacper Niesiecki pisał o nim: „na mądrych ludzi łaskaw, na ubogich i szpitale milosierny". Mecenasowi artystów i ludzi pióra poświęcił kilka strof przyjaciel, Jan Kochanowski, a Szymon Szymonowicz dedykowal mu swe „Sielanki", wydane w 1614 r., stwierdzając przy tym: „,a mnie nie tak do ciebie wiążą twoje główne i wielgomyślne sprawy, jako przyrodzona ludzkość, ode mnie zawsze cale doświadczona".

Kapela i zespół śpiewaków umilały życie gospodarza i jego gości. Kolekcja obrazów w krzepickiej rezydencji człowieka, który przez ostatnie 27 lat swego życia zajmował się budowaniem eremu i kościoła dla kamedułów, pobudzała nie tylko do pobożności. I nie tyle mitologiczne jej tematy, co ich ujęcie wszechstronny esteta uznał za niestosowne, wszakże dopiero wówczas, gdy niebawem miał się z nimi rozstać na zawsze. W swym testamencie polecal bowiem, „aby obrazy do rozpusty i grzechu pobudzające, co ich jeszcze w zamku krzepickim się znajdzie, wszystkie spalić, a te co na murze w mojej izdebce gdziem sypiał $\mathrm{i}$ komnatce nago są namalowane, proszę was, niech malarz, który to potrafi, sukienki jakiekolwiek wymaluje a inhonestas niech pokryje". Podobnego artystę od częściowego choćby przyodziewku dla uczestników Sądu Ostatecznego w Sistinie wynająl dopiero papież Klemens XIII w latach 60. XVIII w. 
Krakowski znawca sztuki renesansu i baroku, Stanisław Tomkowicz, autor liczącej 100 lat malej monografii Bielan, jedno ze źródeł majętności Wolskiego widział w jurgieltach, jakie - podobnie jak niejeden magnat - pobierał od zagranicznych władców za reprezentowanie w Polsce ich interesów, co polegało głównie na kupowaniu szlacheckich głosów na sejmikach i sejmie. Rzecz wymaga oczywiście głębszego zbadania, niemniej trudno przypuszczać, że Wolskiego prohabsburski - powiedzmy - lobbing odbywał się bez żadnych gratyfikacji.

Nie to jednak, ani nie owe plastyczne inhonestates, miały skłonić imć marszałka do fundowania eremu i kościoła. Główną pobudką przedsięwzięcia miały być - jak zapisał o. Placyd, współczesny Wolskiemu kameduła - wyrzuty sumienia $\mathrm{z}$ tego powodu, że przez 12 lat posiadał intratną komandorię joannitów w Poznaniu, nie będąc kawalerem maltańskim (czyżby o tym nie wiedziano dając mu ją?). Z niepokoju swego pan Mikołaj miał się w Rzymie zwierzyć w 1602 r. papieżowi Klemensowi VIII, a ten miał mu doradzić ufundowanie w Polsce klasztoru o ostrej regule, jakiego tu jeszcze nie było.

Skrupuł mało prawdopodobny, spotkanie, owszem, nawet znajomych. Papież, to Ippolito Aldobrandini, nuncjusz w Polsce w latach 1588-1589, który zażegnał spór Zygmunta III z Habsurgami, zapewne nie bez udziału marszałka.

Niezależnie od papieskiej rady czy jej braku, motyw ufundowania pod Krakowem niezwykłego, nieznanego jeszcze w Polsce zakonu, musiał być ważny dla kogoś, kto sam odstawał od seryjnych Sarmatów, nieszablonowo żył i kolekcjonowal unikatowe dzieła. Takim też dziełem staną się Bielany ze swymi zakonnikami i wspaniałą architekturą.

Kameduli przybyli do Krakowa w 1603 r. z Mons Coronae koło Perugii na żądanie Wolskiego, by wybrać miejsce na pustelnię. Wybrali Bielańską Górę, ale ta należała do Sebastiana Lubomirskiego, kasztelana wojnickiego, który swego odstapić nie chciał. Za radą tedy pobożnej kasztelanowej, Wolski uciekł się do fortelu. Wyprawił ucztę, na którą zaprosił ważnych gości. Gdy przybyłym humory już odpowiednio dopisywały, gospodarz zaczął ubolewać, że nie może w swych dobrach znaleźć sposobnego miejsca pod erem. Biskup Bernard Maciejowski i książe Jerzy Zbaraski w przypływie szczodrobliwości zaoferowali do wyboru miejsca w swoich włościach. Wolski zmartwił ich, że nie widzi tam odpowiedniego terenu. Tak zaaranżowania sytuacja obudziła oczekiwaną wspaniałomyślność Lubomirskiego, który zdeklarował gotowość ofiarowania na zbożny cel nie tylko pożądanej góry, ale i wsi Bielany. Akt darowizny był już przygotowany, a kasztelan zdążył go podpisać wcześniej, nim opuścił go wielkoduszny nastrój. W podzięce marszałek ofiarował kasztelanowi użyte do biesiady srebra, skąd i górę, na której miał być erem nazwano srebrną.

Taka opowieść, prawdziwa czy koloryzowana, właczała biesiadny koncept w sakralny cel, uszlachetniała przemyślność, sławiła wspaniałomyślność fundatora.

Kameduli posiadali własne wzorce i przepisy co do swych zabudowań. Ich najpełniejszą realizację stanowi erem w Rytwianach: pustelnia na lesistym wzgórzu i surowy w swej bryle, niewielki kościól. Na Bielanach też miano zrealizować taki model, lecz nie zaakceptował go fundator, który uznał, że można połączyć ascezę mnichów z wystawnością świątyni i sfinansował tę kosztowną dwuznaczność. 
Zmarły w 1620 r. Mikołaj Zebrzydowski przez ostatnie 10 lat życia przebywał najczęściej w kalwaryjskim klasztorze, obchodził Dróżki, doglądał budowy kolejnych kaplic, jakie fundował. Żyjący o 10 lat dłużej Wolski także zamieszkał na górze bielańskiej $w$ jednym z ukończonych budynków klasztornych i osobiście kierował robotami. Człowiek, który w ciagu życia miał wszystko, czego zapragnął, kazał się pochować pod progiem kościoła, w zakonnym habicie, aby - jak pisał w testamencie - ciało jego „deptane było przez przechodniów i opłacało po śmierci wyniosłość swoją i zbytek życia". Łatwy ten i znany gest ostentacyjnej pokory kosztował niewiele, gdy nieubłagalny finał żywota ukazywał vanitas dotychczasowych wspaniałości, wkrótce już bezużytecznych, Za znaczną ich część marszałek wzniósł na odludziu ogromną świątynię dla garstki eremitów.

\section{Nota bibliograficzna:}

C. Erber, Starosta krzepicki Mikolaj Wolski w świetle dedykacji i ikonografii, „Komunikaty naukowe. Seria historyczno-literacka" (Towarzystwo Literackie, Częstochowa), r. 4:1966, nr 5, s. 61-71.

C. Lechicki, Mecenat Zygmunta III i życie umyslowe na jego dworze, Warszawa 1932.

S. Tomkowicz, Bielany, Kraków 1904.

L. Zarewicz, Zakon kamedulów, Kraków 1871.

\section{Summary}

Mikolaj Wolski (1553-1630), founder of the Camaldolese hermitage at Bielany near Cracow, was an exceptionally colourful and interesting personage. He travelled widely in his youth touring the most important European countries and getting familiar with the Renaissance culture. In spite of the fact that he supported a candidate of the House of Hapsburg to the Polish throne, he managed to get appreciation of king Sigismund III, who entrusted him with a position of the Royal Marshal to the Crown and made him his close advisor. Many a time he was sent as an envoy to the pope and monarchs, playing, at the same time, the role of a patron of artists, whom he won not only for the royal palace, but to beautify his own residence in Krzepica. The last 27 years of his life he devoted to the idea of bringing the Camaldolese Order to Cracow and building a hermitage for them on the Bielany Hill. The founder personally supervised construction works and resided in one of the first monastery houses. As an expression of humbleness he wished to be buried after his death under the threshold of the church in a monk's robe. 